Wiesław Ratajczak ${ }^{1}$

Uniwersytet im. Adama Mickiewicza

DOI: https://doi.org/10.26881/jsr.2020.15.11

\title{
„BYL ZAWSZE ARTYSTĄ”. ŚWIĘTY BRAT ALBERT W RELACJACH METROPOLITY ANDRZEJA SZEPTYCKIEGO
}

Wspomnienia Adolfa Nowaczyńskiego o bracie Albercie (tj. Adamie Chmielowskim), choć niezbyt obszerne, zawierają szczególnie interesujący opis wpływu ich bohatera na współczesnych mu artystów, pisarzy, uczonych, ziemian i arystokratów. Tercjarz, który z odwagą i miłosierdziem szedł między najuboższych i najbardziej poniżonych, pociągał swą niezwykłą osobowością także ludzi z kręgów społecznej elity.

Charakteryzując Kraków lat 80. XIX w., Nowaczyński pisał z emfazą o „małym Rzymie", o polskim odpowiedniku Heidelbergu, Oxfordu, Weimaru, Florencji oraz arystokratycznego Paryża jednocześnie, mieście bogactwa, towarzyskiego i intelektualnego wyrafinowania (Nowaczyński 1999, s. 39-40). I dodawał z perspektywy współczesności (wspomnienie ukazało się po raz pierwszy w 1936 r.):

\begin{abstract}
Ewokujemy tu tę grupę socjalną, ten bourgetowski świat i towarzystwo dziś bezpowrotnie już rozpierzchnięte i zagrzebane $\mathrm{z}$ tego powodu, że jeżeli nie w nim samym, to blisko niego znalazł się i przeżywał pewien okres swego żywota przyszły Brat Albert. Przypomina to w swym przepięknym wspominku dzisiejszy metropolita Szeptycki, wówczas (jak i ja jeszcze pamiętam) smukły, szykowny pułkownik ułanów, aranżer prowadzący tańce na balach w ,paradnej” sali hotelu Saskiego. Z malarzem Chmielowskim spotykał się na sympozjach u Konstantego Przezdzieckie$\mathrm{go}^{3}$ na Wolskiej, gdzie synowie historycznych rodów zaprzyjaźniali się z uczonymi, z literaturą, ze sztuką (Nowaczyński 1999, s. 43-45).
\end{abstract}

\footnotetext{
${ }^{1}$ ratajcza@amu.edu.pl, https://orcid.org/0000-0003-3443-4600

${ }^{2}$ Bourgetowski - przymiotnik od nazwiska Paula Bourgeta (1852-1935), pisarza francuskiego, który w powieściach psychologicznych przedstawiał m.in. przejawy i źródła współczesnego pesymizmu.

${ }^{3}$ Konstanty Przezdziecki (1846-1897) - ziemianin, mecenas sztuki i nauki.
} 
Przedstawił więc pamiętnikarz dawną stolicę królów Polski jako nadzwyczajne miejsce spotkań osobowości nieprzeciętnych. Warto jedno z nich wywołać z przeszłości, gdyż dotyczy dwojga ludzi, którzy pozostawili, w rozmaity sposób, głęboki ślad w historii życia duchowego i religijnego. Gdy w 1887 r. spotkali się na Wolskiej w salonie Przezdzieckich, ,czterdziestodwuletni malarz [...] od kilku tygodni nosił szary habit III zakonu franciszkańskiego”, a „dwudziestodwuletni hr. Roman Szeptycki [...] miał rok później wstąpić do zakonu bazylianów i po zmianie obrządku zostać kapłanem greckokatolickim, przyszłym wybitnym lwowskim metropolitą Andrzejem" (Gancarz 2017).

Kolejnym miejscem, w którym przetną się drogi Adama Chmielowskiego i Andrzeja (w świecie: Romana) Szeptyckiego, będzie tatrzańska pustelnia albertyńska. Opis wznoszenia drewnianych budynków w pobliżu drogi na Kalatówki kończył Nowaczyński tak:

I wnet się tu i msze zaczęły odprawiać na miejscu najwyższym w Polsce i najbliżej niebios, wnet rekolekcje przedwielkanocne, na których siadywali obok siebie na zydlach i ksiądz biskup Nowak ${ }^{4}$ (albertynów protektor żarliwy), i dzisiejszy metropolita rusiński Szeptycki, a obok wnuk księcia Adama Czartoryskiego, Zakopanego posiedziciel ${ }^{5}$, a obok niego wnuk Zygmunta Krasińskiego, ordynat z Opinogóry ${ }^{6}$, a obok różni dziwni panowie z całej Polski, brodaci, w pelerynach, których by tam na dole w nizinach nikt nigdy na żadnych rekolekcjach nie uwidział (Nowaczyński 1999, s. 70-71).

Zofia z Fredrów Szeptycka zawarła w swych wspomnieniach m.in. obrazy ze wspólnego z synem pobytu w Zakopanem, gdzie brat Andrzej powracał do zdrowia po ciężkiej chorobie. Młodego duchownego odwiedzali wówczas liczni znajomi:

Jesień, zima, wiosna minęły jak chwile. Nie trwożyła droga i śnieg tych „,mądrych i wiernych przyjaciół”, których Bóg dał. Tak jak swoi zjeżdżali się po kolei do nas: ojciec Jackowski, ks. Skrochowski, Stefański, bazylianie. Godzinami całymi w domku wśród lasu przesiadywali brat Albert, wskrzesiciel tercjarstwa, którego imię w poczcie świętych kiedyś umieszczone będzie; Władysław Zamoyski; malarz-publicysta Witkiewicz ${ }^{7}$ (Szeptycka 1993, s. 173-174).

${ }^{4}$ Anatol Wincenty Nowak (1862-1933) - ksiądz katolicki, biskup pomocniczy krakowski (1900-1924) i biskup przemyski (1924-1933).

5 „Posiedziciel” (posiadacz) Zakopanego to hr. Władysław Zamoyski (1863-1924).

${ }^{6}$ Adam Krasiński (1870-1909) - IV ordynat opinogórski, badacz twórczości Zygmunta Krasińskiego (jego dziadka), pisarz i poeta.

${ }^{7}$ Stanisław Witkiewicz (1851-1915) - malarz, krytyk i teoretyk sztuki, twórca stylu zakopiańskiego w architekturze i sztukach użytkowych, przyjaciel br. Alberta. 
Sprawdziły się przewidywania matki metropolity co do kanonizacji brata Alberta, a choć nie wiadomo, czego dotyczyły owe wielogodzinne rozmowy, przypuszczać można, że miały duże znaczenie dla duchowej formacji młodego mnicha. Najważniejszym świadectwem tego trwałego wpływu osobowości starszego przyjaciela jest spisana w 1934 r. relacja samego metropolity. Hierarcha sporządził ją na prośbę braci albertynów, wówczas aktywnych w gromadzeniu i publikowaniu świadectw życia założyciela zgromadzenia, zapewne w perspektywie procesu beatyfikacyjnego. Metropolita Szeptycki powrócił we wspomnieniu, w którym konwencja hagiograficzna łączy się harmonijnie z tonami głęboko osobistymi, do pierwszych spotkań z Adamem Chmielowskim i podkreślił, że noszony wówczas przez malarza habit tercjarza franciszkańskiego był widomym znakiem decyzji o „porzuceniu świata i poświęceniu się na wyłączną służbę Bogu" (Szeptycki 1934, s. 5). Nie przestawał on jednak - jak dodawał autor wspomnień - być artystą i uczestniczyć w dyskusjach o sztuce. W relacji Szeptyckiego szczególnie ważne i wyraziste jest podkreślanie artystycznego wymiaru osobowości brata Alberta. Odnosząc się do początków swojej drogi jako duchownego (obłóczyn dostąpił 1 lipca 1888 r., po nowicjacie w klasztorze bazyliańskim w Dobromilu), pisał autor wspomnienia:

W latach 1890 i 1891 często widywałem Brata Alberta i bardzo się do Niego zbliżyłem. Uderzał mnie w Jego postaci charakter artysty - jaki mimo woli i wiedzy zachowywał pod grubym już, szarym suknem tercjarskiego habitu. Był zawsze artystą i miał ten rzadki u artystów nawet przymiot; miał bardzo wybitny i bardzo charakterystyczny swój styl. Styl w mówieniu, w przedstawianiu rzeczy, w krytykowaniu tego, co mu się nie podobało, w chwaleniu tego, co lubił. Jego każdy ruch, jego śmiech miały zawsze tyle charakteru, były zawsze czymś tak odrębnym, niezwykłym, że wprost uderzały. Nic nie było w Nim tego, co nazywają oryginalnością: nigdy nie był oryginałem; ale tak był zawsze Sobą. Wszystkiemu, czego się tylko dotykał, nadawał Swój charakter, był taką niepospolitą, tak niezwykłą, tak wyjątkową indywidualnością, że nie mógł nie zwracać na Siebie uwagi, każdego człowieka myślącego i interesującego się tym, co ludzkie (Szeptycki 1934, s. 7).

Warto podkreślić to teologiczne rozumienie zagadnień stylu obecne w relacji metropolity. Sam Chmielowski swoją najważniejszą i najobszerniejszą wypowiedź programową zamknął konkluzją: „Istotą sztuki jest dusza wyrażająca się w stylu" (Chmielowski 1876, s. 431). Jako antytezę sztuki prawdziwej (,,wyrażającej się przez styl, czyli indywidualność duszy”) wskazał wówczas artysta „sztukę fałszywą, udaną, wyrażoną przez manierę, sposób, sztukę nauczoną" (Chmielowski 1876, s. 430). Autentyczność i szczerość staną się więc pojęciami niezbędnymi w próbach uchwycenia ideału sztuki. Można przypuszczać, że do 
tych właśnie słów nawiązywał metropolita Szeptycki, gdy pisał o autentyczności swojego przyjaciela:

Ta dusza dziwnie była daleką od wszystkiego tego, co można nazwać wykrętem, udawaniem, hipokryzją, fałszem czy nieprawdą, była dziwnie szczerą - jak szczere złoto. Prawie, bym powiedział, przezroczystą. Można było w nim wszystko zobaczyć. On nic nie krył, nic nie zasłaniał, chyba cnoty swoje (Szeptycki 1934, s. 8).

Przezroczystość w tym ujęciu okazuje się cechą i warunkiem świętości. Analizując postawę św. brata Alberta, powiedzieć można, że jego przezroczystość przyciągała ludzi, wzbudzała zaufanie również tych, którzy - otoczeni zazwyczaj pogardą - nie mieli powodu ufać komukolwiek, bytując na marginesie społeczeństwa. Cecha ta umożliwiła też stworzenie wokół jego osoby pewnej konstelacji przyjaźni, w której uczestniczyli ludzie o rozmaitych poglądach i postawach. Bez uwzględnienia tego fenomenu obraz kultury polskiej przełomu wieków pozostawałby niepełny. Dla wielu młodopolskich artystów, przeżywających kryzysy duchowe lub deklarujących obojętność, a nawet wrogość wobec religii, mnich-żebrak pozostawał pociągającym, intrygującym przykładem wiary i praktykowania cnót ewangelicznych.

Metropolita nawiązał we wspomnieniu do (opisanych również przez matkę) spotkań z bratem Albertem podczas zakopiańskiej rekonwalescencji - zimą na przełomie lat $1891 \mathrm{i} 1892^{8}$. Z późniejszymi wizytami w pustelni albertyńskiej połączył refleksję o upodobaniu założyciela zgromadzenia albertynów do życia mniszego, odosobnionego:

Drugi raz w Zakopanem spotkaliśmy się kilka lat później; wtedy zawiózł mnie Brat Albert do tej pustelni, zbudowanej daleko w lasach nad Kuźnicami. [...] Gdyby był poszedł za swoim upodobaniem, byłby budował samotne Alwernie i braci swoich byłby wiódł drogami mistycznych

${ }^{8}$ Szerzej na temat obecności br. Alberta w Zakopanem i w samotni przy drodze na Kalatówki pisałem w innym miejscu. Zauważyć można przy okazji, że trwałą cechą charakteru Chmielowskiego była wierność w przyjaźni, wywołującej nierzadko synergię oryginalnych osobowości. W duchowym i materialnym pejzażu Podtatrza utrwalił się ślad współpracy dwojga ludzi o odmiennych temperamentach, innym pochodzeniu społecznym, różnej pozycji towarzyskiej itp. Myślę o br. Albercie i Władysławie hr. Zamoyskim. „Obaj nie byli skłonni do egzaltacji i wylewności, nie pozostawili osobistych wspomnień. Opierając się jednak na przytoczonych relacjach, stwierdzić można, że bez analizy ich wzajemnego wpływu i współpracy trudno w pełni zrozumieć życie Zakopanego przed wybuchem wielkiej wojny. A skoro w tym miejscu ogniskowało się polskie życie kulturalne i polityczne, ta szczególna przyjaźń zakonnika i arystokraty miała niemałe konsekwencje" (Ratajczak 2018, s. 68). 
kontemplacji. Ale któż zajmie się tymi opuszczonymi od wszystkich? (Szeptycki 1934, s. 9)

Przy tak wielkim zaangażowaniu w pomoc najuboższym, przy realizacji przedsięwzięć tak wielowątkowych i skomplikowanych, był - zdaniem Szeptyckiego - brat Albert nie tyle zarządzającym, administratorem, ile ciągle artystą:

Brat Albert nie jest organizatorem; mimo wszystko jest On jeszcze zawsze
artystą. Kiedy rozgada się o artyzmie, o malarstwie, o obrazach, o szko-
łach, o „plain-aire'ach”, to zapomni się, że biedny brat Witalis będzie
musiał dziesięć razy przypominać: ,proszę Brata, już 6-ta godzina”- Brat
Albert nie słyszy i dalej rozmawia - i znowu półgłosem „proszę Brata”
i już dyskretnie za rękaw ciągnie, żeby zwrócić na siebie uwagę (Szep-
tycki 1934, s. 10).

W swym portrecie przyjaciela metropolita uchwycił wielowymiarowość franciszkańskiego doświadczenia wpisanego w jego biografię. Franciszkanizm, nurt tak ważny w epoce współczesnej Chmielowskiemu, był przez niego praktykowany w sposób pełny: przez wstręt do bogactwa, upodobanie w ubóstwie i prostocie, wrażliwość na każdy przejaw ludzkiej nędzy, wrażliwość na piękno natury i bliski z nią kontakt. Nie zabrakło w tym doświadczeniu także elementu cierpienia, niejako skrywanych stygmatów, bólu znoszonego bez skargi i w tajemnicy. Pisał o tym Szeptycki:

Nieraz nocowałem w schronisku z Bratem Albertem w jednym pokoju i byłem świadkiem, jak ciężki był Jego odpoczynek; godzinami całymi nie sypiał; czy ból nogi, czy twarda deska - dosyć, że o jakiejkolwiek godzinie w nocy budziłem się - prawie zawsze spostrzegałem, że Brat Albert nie śpi (Szeptycki 1934, s. 10).

Charakter tych wspomnien - skoncentrowanych na osobistych wrażeniach, na próbie opisania przemian życia artysty, na rejestrowaniu obyczajowych detali - daleki jest od konwencjonalnego zapisu heroiczności cnót kandydata na ołtarze. Wyraźnie widać, że hierarcha Kościoła pisze o przyjacielu i mistrzu, o wrażliwym artyście i cierpiącym człowieku.

Mówiąc o ich wzajemnych relacjach, nie sposób nie wspomnieć o dziejach obrazu Ecce homo. Jego powstanie wiąże się z pobytem Chmielowskiego we Lwowie, gdzie „w latach 1879-1880 mieszkał [...] razem z Leonem Wyczółkowskim" (Nowobilski, Żmudziński 2016, s. 15). W stolicy Galicji powstawały obrazy religijne, a najważniejszym z nich był „Ecce Homo, z którym to obrazem artysta nie rozstawał się przez długi czas. Ten zwrot ku malarstwu religijnemu był niewątpliwie wynikiem duchowych poszukiwań kontaktu z Bogiem" (No- 
wobilski, Żmudziński 2016, s. 15-16). Warto podkreślić - w kontekście relacji malarza z metropolitą lwowskim obrządku wschodniego - że początek prac nad obrazem miał związek z grecko-katolicką cerkwią Świętego Ducha (Tatar 2014, s. 112). Wyczółkowski, autor słynnego portretu brata Alberta z 1934 r. ${ }^{9}$, należał do świadków powstawania Ecce homo. Pisał o tym dziele trafnie, poetycko i lapidarnie, potwierdzając jednocześnie zażyłość malarza z greckokatolickim hierarchą:

Najgłębszy wyraz u Chrystusa dał Adam Chmielowski w Ecce Homo. Szary dzień, deszcz pada, Chrystus skatowany, oczy zapadnięte w głąb. Tak się stało i tak się stać musiało. Chrystus zmęczony, stargany, oplwany, szmatą purpurową spowity, ale oczy patrzą w głąb. Dziś własność metropolity Szeptyckiego, z którym Chmielowski żył w serdecznych stosunkach (Wyczółkowski 1960, s. 205-206).

Ze wspomnianym płótnem Chmielowski długo się nie rozstawał, „woził je ze sobą wszędzie” i „nie potrafił ukończyć” (Budzyńska 2017, s. 279). Studium i kontemplacja twarzy Zbawiciela stały się elementem drogi artysty i - jak to zasugerował w dramacie Brat naszego Boga Karol Wojtyła (2007, s. 315-392) odegrały ważną rolę w wyborze powołania bezwarunkowej służby ubogim. Zdaniem ks. Dariusza Radziechowskiego przemiana bohatera sztuki Wojtyły dokonała się dzięki zrozumieniu istoty związku piękna z miłosierdziem (Radziechowski 2017, s. 118-122). O spójni tej mowa w jednym z monologów, wygłoszonym w pracowni przed ciągle niegotowym niepokojącym obrazem Ecce homo:

- Jesteś jednakże straszliwie niepodobny do Tego, którym jesteś -

Natrudziłeś się w każdym z nich.

Zmęczyłeś się śmiertelnie.

Wyniszczyli Cię -

To się nazywa Miłosierdzie.

$--$

Przy tym pozostałeś piękny.

Najpiękniejszy z synów ludzkich.

Takie piękno nie powtórzyło się już nigdy później

- O, jakież trudne piękno, jak trudne.

Takie piękno nazywa się Miłosierdzie (Wojtyła 2007, s. 363).

${ }^{9}$ Wyczółkowski tak scharakteryzował własne dzieło: „Brat Albert z dzieckiem na ręce. Wór szary, deszcz siąpi, brat Albert tuli dziecko rachityczne. Prostoty większej nie może być" (Wyczółkowski 1960, s. 163). 
Autor komentarza dostrzegł w cytowanych słowach rozwinięcie starożytnej formuły Khalepà tà kalá ('Piękno jest rzeczą trudną') poprzez jej połączenie z chrześcijańskim orędziem miłosierdzia (Radziechowski 2017, s. 120).

W Darze i tajemnicy, książce o sensie kapłaństwa, Jan Paweł II w kontekście własnych doświadczeń duchowych powrócił do tej idei i do wyboru dokonanego przez malarza:

W dziejach polskiej duchowości św. Brat Albert posiada wyjątkowe miejsce. Dla mnie jego postać miała znaczenie decydujące, ponieważ w okresie mojego własnego odchodzenia od sztuki, od literatury i od teatru, znalazłem w nim szczególne duchowe oparcie i wzór radykalnego wyboru drogi powołania (Jan Paweł II 2005, s. 25) ${ }^{10}$.

Na prośbę Szeptyckiego, wspartą datkiem dla ubogich, brat Albert nie zaprzestał pracy nad dziełem i ostatecznie ofiarował je lwowskiemu metropolicie. Tak o 1884 r., w swej dotąd niepublikowanej obszernej biografii świętego, pisał ks. Czesław Lewandowski:

W tym czasie zabrał się Brat Albert do wykończenia głowy Chrystusa, czyli Ecce Homo, do czego go prawie przymusił ks. metropolita Szeptycki, wręczając zadatek pieniężny dla ubogich. Pod takim moralnym przymusem wykończył Brat Albert to arcydzieło w swej pracowni na Skałce, a potem przeniósł czasowo atelier do sali ogrzewalni dla mężczyzn przy ul. Piekarskiej, gdzie umyślnie na ten cel okno dorobił ku Skałce, i wykończywszy obraz, oddał Księdzu Metropolicie (cyt. za: Mróz 2006, s. 137-138).

Ks. Lewandowski zanotował często cytowane później zdanie malarza, z lekką ironią dającego do zrozumienia, że był już pochłonięty innymi niż artystyczne zatrudnieniami: „Obszedłem się z tym obrazem jak partacz ostatni, lecz tak mnie molestował metropolita, że aby mieć spokój, dokończyłem go po rzemieślniczemu" (cyt. za: Budzyńska 2017, s. 280).

Początkowo grekokatolicki hierarcha przechowywał dzieło w swoim mieszkaniu, później jednak przekazał je do muzeum, „pragnął zapewne, by obraz ten był podziwiany w galerii muzealnej, a nie zamknięty w czterech ścianach prywatnego apartamentu" (Nowobilski, Żmudziński 2016, s. 21). W 1939 r. wizja

${ }^{10}$ To oczywiste, że rezygnacja z teatru nie oznaczała rozbratu K. Wojtyły ze sztuką. Także wobec Jana Pawła II można bez wątpliwości odnieść formułę z tytułu niniejszego szkicu: „Był zawsze artystą”. Rozumienie i praktykowanie „stylu” ujawnia wiele podobieństw obu świętych, a w pewnym sensie pozwala mówić o relacji mistrz - uczeń, której realizowania nie utrudniał brak fizycznej obecności br. Alberta. 
Miłosiernego eksponowana była na retrospektywie Adama Chmielowskiego w Muzeum Narodowym w Warszawie. Niezwykle skomplikowane wojenne i powojenne losy wizerunku, żmudne koleje jego wydobycia ze Związku Sowieckiego $^{11}$, a później nadzwyczajny kult - nasuwają skojarzenia z losami pierwszego obrazu Jezu, ufam Tobie namalowanego według wskazówek św. Faustyny Kowalskiej przez Eugeniusza Kazimirowskiego w 1934 r. Porównanie historii, ikonografii i kultu obu religijnych przedstawień to temat na osobne studium.

Niezwykle ciekawe świadectwo dotyczące sposobu odczytywania dzieła Chmielowskiego przez metropolitę Szeptyckiego odnotował ks. Konstanty Michalski w relacji opublikowanej na łamach pisma „Głos Brata Alberta” w 1938 r. Dwa lata wcześniej, będąc we Lwowie, biograf postanowił zobaczyć obraz Ecce Homo w pałacu arcybiskupów na świętojurskim wzgórzu. Okazało się jednak, że dzieło zostało przekazane do muzeum. Metropolita, wówczas już ciężko chory, chciał wspólnie z gościem ponownie spojrzeć na płótno, dlatego zaproponował spotkanie następnego dnia, gdy obraz zostanie specjalnie przyniesiony do mieszkania. Nazajutrz arcybiskup Szeptycki w wyjątkowo nowatorski i emocjonalny sposób zinterpretował Ecce homo:

Niech ksiądz patrzy, wołał z uniesieniem, niech ksiądz patrzy. To przecież nowy, genialny sposób przedstawienia Serca Pana Jezusa. Picasso czasem zniekształcał jakieś szczegóły w budowie anatomicznej człowieka, kiedy chciał wydobyć na wierzch niedostępny dla innych szczegół duszy. Brat Albert zdeformował trochę ramię Chrystusa, lecz co z tego wyniknęło? Niech ksiądz popatrzy. Czerwona chlamida opada z ramion tak, że zarysowuje się na ubiczowanej piersi Chrystusa olbrzymie serce. Cały Chrystus zamienia się w serce. To zbiczowane Boże Serce” (Michalski 1978, s. 25).

Skojarzenie techniki malarskiej Chmielowskiego z warsztatem Picassa zaskakuje, świadczy jednak o niezwykłej erudycji i spostrzegawczości Szeptyckiego, który zaproponował przekonującą, teologiczną interpretację zastosowanej przez polskiego malarza deformacji ciała Jezusa. Zauważyć można, że podobnie (trudno ocenić, czy niezależnie od Szeptyckiego) słynny obraz odczytał kardynał Franciszek Macharski. Wielokrotnie w swoich wystąpieniach i pismach nawiązywał on do najsłynniejszego malarskiego dzieła Chmielowskiego. W 1981 r. mówił:

„Oto Syn mój umiłowany”. Umiłowany... Tak bardzo wpatrzył się Brat Albert w Chrystusa, którego mu pokazywał Ojciec niebieski; Jezusa ubiczowanego i oplwanego; Boga ukrzyżowanego, a równocześnie zmar-

${ }^{11}$ Okoliczności odzyskania i przewiezienia obrazu do Polski przedstawił w swoim artykule J. Majda (2010); wcześniej o losach obrazu pisała s. A. Faron (1998). 
twychwstałego i pełnego mocy. Tak się głęboko w Niego wpatrzył, że w rysach Chrystusa ukrzyżowanego dostrzegł rysy człowieka. Zwyczajnego człowieka: tego z ulicy Krakowskiej i z Kazimierza, i Podgórza; tego człowieka zwyczajnego, opuszczonego, który nie miał gdzie głowy skłonić i lądował w przytułku; człowieka smutnego, zapitego, zaniedbanego, brudnego, człowieka złodzieja, człowieka z marginesu (Macharski 2015, s. 35).

Trzy lata później Macharski niejako uzupełnił zanotowane przez ks. Michalskiego słowa lwowskiego hierarchy, pisząc o św. bracie Albercie następująco:

[...] przylgnął do tajemnicy Jezusa ogołoconego i opuszczonego. Wyraził ją pędzlem artysty w urzekającym obrazie pt. Ecce homo, gdzie ślady męki i pohańbienia układają się w zarys Serca (Macharski 2015, s. 78) ${ }^{12}$.

Relacja arcybiskupa Szeptyckiego ze św. Albertem zyskała niedawno kolejną, nieoczekiwaną kontynuację. Jako autor wspomnień metropolita stwierdził przed laty, że starszy przyjaciel podzielał jego troskę i uczucie wobec ludu ukraińskiego. Postawa ta miała być zakorzeniona w przeżyciach z dzieciństwa:

W otoczeniu, w którym wzrastał, uchodziło wszystko, co ukraińskie, ruskie, za coś idealnego, ciekawego, pięknego i chwalebnego; stąd może zachował Brat Albert bardzo szczerą życzliwość dla bratniego ukraińskiego narodu, choć nigdy nie interesowały Go żadne sprawy polityczne i nawet, zdaje się, najmniejszego zmysłu do polityki nie miał (Szeptycki 1934, s. 8).

W świetle tych słów odczytać warto informację podaną przez lwowski „Kurier Galicyjski”, że 22 lipca 2017 r. w greckokatolickiej katedrze św. Jura i rzymskokatolickiej archikatedrze Wniebowzięcia Najświętszej Maryi Panny we Lwowie zakończyła się pierwsza Międzynarodowa Ekumeniczna Piesza Pielgrzymka Pojednania szlakiem św. brata Alberta i klasztorów bazyliańskich. Błogosławieństwa pątnikom, którzy wyruszyli ze wsi Prusie koło Werchraty na Roztoczu, udzielił papież Franciszek. Była to okazja, by przypomnieć pielgrzymi wymiar życia św. brata Alberta, gdyż ten wielekroć ,przemierzał szlak ze

${ }^{12}$ Interpretacyjne intuicje obu duchownych, Szeptyckiego i Macharskiego, zdaje się potwierdzać analiza przeprowadzona przez A. Żukowską: „Purpura dynamicznie namalowanej szaty Chrystusa odbija się krwawym refleksem na Jego umęczonej twarzy, pozbawionej naturalistycznie odtworzonych ran. Opadająca z ramion szata obnaża rozświetloną pierś splątaną powrozem, która przybiera symboliczną formę Odkupieńczego Serca Chrystusa. Natężenie fizycznego cierpienia i mistycznej koncentracji oddaje złocisty płomień, przenikający ledwo zauważalną aureolę" (Żukowska 2013, s. 178). 
Lwowa do Krakowa i budował po drodze przytułki dla ubogich. Bywał m.in. w greckokatolickiej katedrze św. Jura we Lwowie i gościł u abpa Andrzeja Szeptyckiego - greckokatolickiego metropolity lwowskiego, z którym łączyły go więzy przyjaźni” (Czawaga 2017) ${ }^{13}$.

Przyjaźń między bratem Albertem a metropolitą Andrzejem Szeptyckim jest istotnym faktem z ich biografii. Obaj - wrażliwi na malarstwo - medytację dzieł sztuki uważali za ważną część życia duchowego. Cenili najwyżej ideał kontemplacyjnego życia mnicha, a jednak gotowi byli z niego rezygnować, podejmując zadania wobec wspólnoty. Oryginalna formuła „Był zawsze artystą” pokazuje spójność biografii, w której tak ważną rolę odegrały odpowiedź na powołanie i radykalna przemiana życia.

\section{Bibliografia}

Budzyńska N. (2017), Brat Albert. Biografia, Kraków.

Chmielowski A. (1876), O istocie sztuki, „Ateneum. Pismo naukowe i literackie" t. 2, z. 4.

Czawaga K. (2017), Pielgrzymka Pojednania szlakiem św. Brata Alberta, „Kurier Galicyjski” nr 14 (282), http://www.kuriergalicyjski.com/spoleczenstwo/ religia-kg/6152-pielgrzymka-pojednania-szlakiem-sw-brata-alberta.

Faron A. (1998), Ecce Homo. Historia obrazu, Kraków.

Gancarz B. (2017), Metropolita i szary brat, „Gość Krakowski” (dodatek do „Gościa Niedzielnego”) nr 12, http://krakow.gosc.pl/doc/3760610.Metropolita-i-szary-brat.

Jan Paweł II (2005), Dar i tajemnica, w pięćdziesiąta rocznicę moich święceń kapłańskich, Kraków.

Macharski F. (2015), Z bratem naszego Boga, oprac. J. Poniewierski, Kraków.

Majda J. (2010), Prawda o odzyskaniu Ecce Homo, „Dziennik Polski” z 27 VIII.

Michalski K. (1978), Brat Albert, Poznań.

Mróz F. (2006), Pielgrzymowanie do sanktuarium Ecce Homo św. Brata Alberta w Krakowie, „Peregrinus Cracoviensis” z. 17.

Nowaczyński A. (1999), Najpiękniejszy człowiek mego pokolenia Brat Albert, wstęp, oprac. i komentarze J.A. Malik, Lublin.

${ }^{13}$ Autor relacji cytował słowa ks. dra Ryszarda Podpory, przewodnika pielgrzymki. 
Nowobilski A.J., Żmudziński J. (2016), Św. Brat Albert, w: Święty Brat Albert 1945-1916, koncepcja, oprac. i red. A.J. Nowobilski, Kraków.

Radziechowski D. (2017), Piękno i miłosierdzie (Brat Albert Chmielowski i Karol Wojtyła), w: Odsłony miłosierdzia, red. Z. Zarębianka, K. Dybeł, Kraków.

Ratajczak W. (2018), Św. Franciszek, św. Albert i Władysław Zamoyski. Wyimek z duchowej historii Zakopanego, „Pamiętnik Biblioteki Kórnickiej” z. 31.

Szeptycka z Fredrów Z. (1993), Młodość i powołanie ojca Romana Andrzeja Szeptyckiego zakonu św. Bazylego Wielkiego, opowiedziane przez Matke jego 1865-1892, oprac. B. Zakrzewski, Wrocław.

Szeptycki A. (1934), Ze wspomnień o Bracie Albercie, Kraków.

Tatar M. (2014), Od duszy artysty do artyzmu ducha św. Brata Alberta, „Collectanea Theologica" 84/1.

Wojtyła K. [Jan Paweł II] (2007), Brat naszego Boga, w: Poezje, dramaty, szkice. Tryptyk rzymski, Kraków.

Wyczółkowski L. (1960), Listy i wspomnienia, oprac. M. Twarowska, Wroclaw.

Żukowska A.M. (2013), Obraz Ecce Homo (1879-1881) Adama Chmielowskiego, „Religious and Sacred Poetry: An International Quarterly of Religion, Culture and Education" No. 2 (2).

\section{Streszczenie „Był zawsze artystą". Święty brat Albert w relacjach metropolity Andrzeja Szeptyckiego}

Adam Chmielowski, znany jako św. brat Albert, był malarzem, mistykiem i sługą ubogich. Wywarł szczególny wpływ na współczesnych mu artystów, pisarzy, uczonych, ziemian i arystokratów. Jego osobowość fascynowała, a wzór życia stanowił wyzwanie dla współczesnych. Tematem artykułu są relacje między nim a Andrzejem Szeptyckim, lwowskim metropolitą Kościoła greckokatolickiego. Łączyła ich wieloletnia przyjaźń, z inspiracji hierarchy Chmielowski dokończył swój najbardziej znany obraz - Ecce homo. Wspomnienia metropolity ukazują wielowymiarowość franciszkańskiego doświadczenia wpisanego w biografię świętego. Są też próbą uchwycenia osobowości artysty.

Słowa kluczowe: franciszkanizm, świętość, autentyczność, pamięć, artyzm, miłosierdzie, pamięć 


\section{Summary \\ "He was always an artist". St. Brother Albert in the memoirs of Metropolitan Andrzej Szeptycki}

Adam Chmielowski, known to the world as St. Brother Albert, was a painter, mystic and servant of the poor. He had a special influence on contemporary artists, writers, scholars, landowners and aristocrats. His personality was fascinating, and his pattern of life was a challenge for his contemporaries. The content of the article is the relationship between him and Andrzej Szeptycki (Andrey Sheptytsky), the Lviv metropolitan of the Greek-Catholic Church. They shared a long friendship, inspired by the hierarch, Chmielowski finished his most famous painting -Ecce Homo. The memories of the metropolitan show the multidimensionality of the Franciscan experience inscribed in the saint's biography. The notes are also an attempt to capture the artist's personality.

Keywords: Franciscanism, holiness, authenticity, memory, artistry, mercy 